\title{
A Contribution to the Sociology of Modern Work
}

Name: Paulo Pereira de Almeida

Academic affiliation: University Professor

Mailing address: ISCTE-IUL - Av das Forças Armadas, Cacifo 4 - 1649-026 LISBOA - PORTUGAL

Contact phone: +3517935000

Email address: papa@iscte.pt

\begin{abstract}
The present article presents several results of the author's ten years investigations about the world of work in the dusk of the $20^{\text {th }}$ century and at the dawn of the $21^{\text {st }}$, and is also a contribution to the Sociology of Modern Work.

Hence the article focuses on current divisions and boundaries in the Sociology of Work, reflects on the post-Taylor paradigms in modern work, work in the digital age, work in network, and depicts the logic and organisation of modern work in services. The article ends with a reflection on the current issues involved in a specific phenomenon: the servicelisation of modern work.
\end{abstract}

Keywords: sociology of work; modern work; services; servicelisation; networks; action communities 
The changes in workers' lives and the world of work at the beginning of the $21^{\text {st }}$ century have varied greatly in nature and social extent. We may consider, for example: (1) the intense, worldscale competitiveness arising from the globalisation of people and markets; (2) the mass use of electronic devices in work organisations and leisure activities; and (3) the worldwide flows and migratory movements of enterprises, organisations and workers, with their impact on jobs available, qualifications, skills, and forms of organisation (Auster, 1996; Boreham, 2008; Williams and AdamSmith, 2006).

Though representing nothing new, the "commercialisation" of work, the ever-closer integration of the public service and private sphere, and the need to make working times and rhythms more flexible mean that paid work itself is increasingly seen in a different light. Various authors mention the demise of the concept of "a job for life", a phenomenon matched with the decline in the existence of a single "breadwinner" in the family (Grint, 2005; Reich, 2004; Schnapper, 1998).

The field of the sociology of work is thus being transformed into a multidisciplinary and interdisciplinary area - a debate that accompanies the revival of post-1980s sociological discussions and is closely connected with the workplace and its central role in human labour activities. More markedly interdisciplinary after a period of a certain paradigmatic hesitation ${ }^{1}$, the sociology of work in the first decade of this century remained in this dialectic movement, with natural moments of retraction and expansion, to which strategies for affirming fields of institutional autonomy and independence of object are not unrelated.

\section{Current divisions and boundaries in the Sociology of Work}

An examination of the interconnections between work and the various social spheres allows us, then, to mention four dimensions on which to centre the discussion: (1) the production, distribution, exchange and consumption process; (2) the boundaries between paid and unpaid work in the formal and informal sectors; (3) the process of coordination with non-work activities; and (4) time and its relationship with the three foregoing dimensions. 
To the discussions of the 1990 s we should add that of the interdisciplinary relationship between economics and the sociology of work. In our view this problematisation initiates and indicates a movement towards some of the approaches to work in services, with a distinction between an "industrial logic" and "service logic": if, in industrial organisation, most human work is essentially an undifferentiated supply of service to machines (with work productivity being directly related to that of these machines), service organisation demands human resources with personal capacities (initiative, adaptation to different circumstances, the definition and organisation of the work itself) according to a system of "co-production" with the customer (Almeida, 2005a; 2005b; 2009a).

\section{The post-Taylor paradigms in modern work}

The 1980s and 1990s were marked by the prevalence of the technical dimension in human work activities: if just-in-time practices and quality policies extended the types and codes associated with work-related ways of operating, the introduction of semi-independent groups and the elimination of management levels conditioned work in the opposite direction (Boreham, 2008; Kóvacs and Castillo, 1998; Zarifian, 2003).

For work on physical matter ever more complex technical mediations are introduced; for interaction among workers it is necessary to understand the so-called trend towards tertiarisation and transversality for the "logic of service. Within this rationale that, in the first decade of this century, we had the opportunity to conduct an investigation that took a multi-dimensional approach to the dynamics of enterprises in the fields of financial services, telecommunications and computing, specifically regarding the use of information technology (IT). So the research was restricted to a universe in which the enterprises were all heavy consumers of "IT resources" and, in some cases, key software-development partners of other companies, especially in the multinational sphere. In these companies, the IT component was particularly pronounced. Consequently, it was possible to see the

\footnotetext{
1 We may recall, for example, the debates of the 1970s and 1980s on the conceptual field of the sociology of work and the sociology of employment. And, more in the present day, the debate on the end of human work and, thus, of a discipline - a branch of science that would be at risk of losing its purpose...!

2 The concept of "co-production" leads us to the dimension of work as a social relationship, and to the leading actors in this relationship. There are, indeed, elements that bind the individuals, the actors, who "enter a relationship" in a certain context and situation and represent the protagonists in them. And if we speak of the "protagonists" of the relationship, it is to avoid a purely functionalist definition and call attention to the fact that - used outside the "capital-work relationship" - that social relationship is composed of a set of specific interactions constantly repeated in space and time.
} 
results as trends and, in some cases, they served to identify good national practice and to disseminate innovative experiences that could have mobilising effects on other business sectors. The study - for which the field work was carried out in 2003 - developed and collected data on four basic indicators: (1) use of IT, the labour market and enterprises; (2) the information system and use of technology; and (3) e-mail and internet use; and, finally, (4) forward-looking indicators that included the question of IT and the enterprises' future investments. The approach, therefore, clearly reflected the technological dimension (table 1):

Table 1. Synopsis of the Conclusions of the Research Project on Information Technology (IT) Use in Financial Intermediation Enterprises (2000)

“(...) On the question of the purposes of e-mail use, the enterprise managers underline three aspects: its use as a communication tool, a business tool and an e-learning tool. It is also worth mentioning not only how it is integrated into business processes and those relating to the organisation but also how it is regularly used in the customer relationship. In the enterprises studied, the internet is widely used and is integrated into daily work routines.

With regard to the purposes of its use, the interviews contained references to the sharing of experience among the subsidiaries of multinational companies and to the development of whole information systems on this tool; thus, there is internet-supported - training, experience sharing, idea swapping, virtual relations between 'business communities', information release, and business process integration. Moreover, companies use e-commerce with a twin target in view the internal customer-base and sales to external customers; thus, in the managers' replies we found references to the sharing of services, the relationship with suppliers, and sales through virtual sites."

Following the line of thought that we have been developing in earlier work, papers and research, we attach importance to the findings that a large part of the work in services runs against the flow of industrial models. (Almeida, 2005; 2008; 2009a).

Though certain elements remain constant, the speed of operations (which justified taking advantage of the qualities of systems and machines) has become out of step with the demands of initiative, practical intelligence, communication with colleagues, and dialogue with customers (which represents a large part of the contemporary activities of human work). It is therefore argued that the tertiarisation of economic activities alters the kinds of skill demanded of workers: this "logic of service" is commonly associated with a particular centrality of the "skills model", which can also be associated with the centrality of skills/competence, per se, in human work activities (Almeida, 2005; Aubret, 2002; Gadrey and Zarifian, 2002; Stone, 2009). 
What appears to us to be really important in this phase is a gradual, though consolidated, transition towards the dematerialisation of human work activities. This will be clearer if we pay particular attention to the forms of providing a service and the related functional division of the operations carried out. For example, according to Gadrey, service activities are performed on the basis of a framework that considers (Gadrey, 1996; Gadrey, 2000): (1) logistical and material manufacturing operations (with tangible objects to manufacture, move or maintain, as in the case of merchandise to be received, added to stocks, and displayed to the public in the retail trade); (2) operations involving information logistics, activities that consist of producing, gathering, processing and circulating codified information (administrative, financial/accounting, and statistical), in the standardised form of files, documents and printed forms (in the retail trade, this covers information on the management of transactions, stocks, prices etc.); and (3) direct-service activities, in a more or less interactive relationship with customers or users, in which case the customers/service-users themselves are the principal support (for this particular, we talk of co-production in an immaterial dimension).

With regard to this immateriality of service activities - a frequent term of reference in contemporary management language, which often uses the jargon "process dematerialisation" - we can find it in two investigations that we conducted in succession at the beginning of the last decade (table 2; table 3):

Table 2. Synopsis of the Conclusions of the Research Project on Information Technology (IT) Use in Financial Intermediation Enterprises (2000)

“(...) The financial organisations analysed are all heavy consumers of IT resources and, in some cases, key software development partners of other companies, especially in the international sphere. The concern with technical assistance and future upgrades has a decisive influence in the choice of these partnerships. The strategies used in the creation and/or implementation of a piece of IT software vary in accordance with the size and positioning of the enterprises analysed. The contribution of these IT areas to enterprise strategy is generally thought to be considerable, with the employees' performance being of fundamental importance, on both the systems and communications sides. In two of the cases studied, a Department of New Technology was specifically created, alongside an existing Computer Department."

Table 3. Synopsis of the Conclusions of the Research Project on Information Technology (IT) Use in Financial, Telecommunications and Computer Enterprises (2003) 
"(...) With regard to the forms in which enterprises are provided with IT, it is worth mentioning that positions vary significantly. There are references to IT training and development on the basis of in-house skills, as well as to self-developed IT skills, complementary training (of a behavioural nature) or, again, the establishment of partnerships with universities on an informal level (contacts) and formal level (specific requests), aimed at filling gaps in training.

In the enterprises analysed, it no longer makes sense to speak of policies to encourage IT use. Its integration into the management model and information systems is considered a given, though two new trends are beginning to appear: the combination of IT and remote access; and widespread laptop use associated with an idea of mobility (although advantage is not yet being taken of the fastest internet connections, namely ADSL and broadband). In fact, a highly significant percentage of references (72\%) is to remote access to enterprise information systems for over $50 \%$ of their functions. This access has, essentially, three purposes: access relating to telework for maintenance reasons; free access by employees in general to consult personal information; and access driven by commercial needs."

\section{Work in the digital age}

In combination with the globalisation movement, technology has been transformed into an important work-rationalising instrument: addressing the technological issue implies, additionally, specifying the alternatives for the design of an organisation. Among the alternative models for organising human work it is important to identify one in particular (perhaps the one that is used most spontaneously in the business world), which sees the "organisation as a structure". In real life, the structure may alter, be distorted or disappear but it has a material existence that grants it a certain stability and introduces the "key markers" for the organisation's members.

The literature associates structure, in general, and technology, in particular, with rationalisation processes, i.e. as though both are the product and at the same time the reflection of three processes: (1) a process of the division of labour in the whole of global organisation; (2) a process of coordination between the entities thus divided up; and (3) a control system, often close to coordination. In this architecture we find classical postulates, e.g. the Fayolist postulate of differentiation and the Taylorist of specialisation, as well as new organisational postulates, e.g. that of the formation of "identities associated with project groups" and "multi-skill communication networks".

Technological work networks are thus indispensable to the complex work of advanced capitalist societies and, as such, gain increased importance, in particular, for (among other aspects) 
the exchange of ideas, the sharing of experience, and virtual relationships among "business communities" ${ }^{\prime 3}$. This was a finding of one of the investigations that we carried out between 2002 and 2003 (table 4):

Table 4. Synopsis of the Conclusions of the Research Project on Information Technology (IT) Use in Financial, Telecommunications and Computer Enterprises (2003)

“(...) On the question of the purposes of e-mail use, the enterprise managers underline three aspects: its use as a communication tool, a business tool and an e-learning tool. It is also worth mentioning not only how it is integrated into business processes and those relating to the organisation but also how it is regularly used in the customer relationship. In the enterprises studied, the internet is widely used and is integrated into daily work routines.

With regard to the purposes of its use, the interviews contained references to the sharing of experience among the subsidiaries of multinational companies and to the development of whole information systems on this tool; thus, there is internet-supported - training, experience sharing, idea swapping, virtual relations between 'business communities', information release, and business process integration. Moreover, companies use e-commerce with a twin target in view the internal customer-base and sales to external customers; thus, in the managers' replies we found references to the sharing of services, the relationship with suppliers and sales through virtual sites."

\section{Work in network}

The organisational development and human resource management techniques that characterised the 1990 s contributed to the appearance of what Coutrot termed the "neoliberal regime of mobilisation" (Coutrot, 1998): key-sectors of capital accumulation (the chemical, pharmaceutical, vehicle and electronics industries, business services, large-scale distribution services etc.) saw changes in their performance criteria. It became essential for management not only to reduce costs and create economies of scale but also to improve quality, extend product and service ranges, and be able to react to the needs of customers, show adaptability, and innovate on the product and procedures front.

As we see it, what distinguishes networks from hierarchical structures nowadays is one of the central issues to an understanding of the recent phenomena of "capillarity" in the networks of human work (Caron, 2002; Veltz, 2000). Terms such as "public policy networks" and "network

\footnotetext{
3 In addition to this concept of "business communities", we address the concept of "action communities" at a later point in this text.
} 
management" are increasingly used and applied in the real life of modern work organisations. For example, in the field of public administration, the state is now more fragmented and has more departments (Bilhim, 2001; 2008): citizens expect a wider range of services, more information, better communications, and greater facility in public decision-making. Public service structures now involve greater coordination between different departments, who should work together to reach their goals, with the organisation duly aligned with skills and training (Bilhim, 2008).

Progressive servicelisation and the technological focus of activities involving work in networks - as we explained in the preceding section of this article - also have an influence, in their own way, on the creation of work and representation universes, which Zarifian terms "action communities" (Zarifian, 2003; 2009). In our view, we are considering a concept that is operating to a certain extent, despite its need for further development. Zarifian judges that organisations, as action communities, are mainly formed around "postures", which are gradually transformed into "habits" (Zarifian, 2003; 2009): (1) the posture of open dialogue between professionals, even if initially acquired by the process of re-socialisation, may later become "natural"; (2) an organisation is thus created that may be very simple in structure and even in its operating rules, one that arises from a need for simplification and de-bureaucratisation that is associated afterwards with a nomad community in its activities of work that - almost spontaneously - simplifies that organisation.

It is especially in the 1990s that the notion of flexibility becomes almost universal and is transformed into a strategic goal for corporate human resources management. There are essentially two explanations for this phenomenon: (1) enterprises lay the stress on reducing unit production costs, either by eliminating workers who do not contribute directly to this production or reducing the costs of the directly productive workforce; (2) this phenomenon corresponds to the corporate ability to adjust the size and mix of work inputs to changes in the demand for products, so that the costs of the "surplus" work are not supported by the organisation costs 4 .

We are also dealing with a reconfiguration of the ties in organisations: (1) the search for a more intense mobilisation of the human resources in modern management theories seems to result as much from an awareness of their intrinsic importance as (2) from the imperatives of

\footnotetext{
$4 \quad$ It is worth noting that flexibility entrains the segmentation of the workforce in the management of organisations: enterprises now use employment as an adjustment variable. This tends to cause a division between "core workers" and "peripheral workers", a concept that has been well explored in labour market segmentation theories.
} 
organisational effectiveness or, again, (3) from the need to guarantee the success of investment in new technology by means of the associated dynamics of re-skilling and skill development.

It should be understood that the issue here is the capacity to strike a virtuous balance between challenges for an organisation's performance and mechanisms for improving that performance and human work, in the different subsystems for assessing performance. This should take into account that, in our view, these subsystems contribute to the creation of microcosms or tribes of wage-earners and workers in accordance with the new segmentations induced and introduced by the assessment, with a significant impact on levels of identification, ties and conflict.

\section{The logic and organisation of modern work in services}

The notion of the tertiary sector originated with Fischer, who presented the services sector for which he coined the term "tertiary" - as the new component in the world economic system (Fischer, 1935). In a second piece of work, dating from 1945, the author states that economic activities can be divided into three categories: (1) "primary production", which includes agricultural and mining work, whose direct purpose is the production of food and different raw materials; (2) "secondary production", which covers manufacturing industry in all its forms; and (3) "tertiary production", which takes in the (huge) remaining group of activities dedicated to the supply of "services". These include transport, trade, leisure and education/instruction, in addition to all the highest forms of philosophy and artistic creation (Fischer, 1945).

Clark, however, is cited as the first author to make these concepts operational - "primary sector", "secondary sector" and "tertiary sector". He established the fundamental grouping of the economic production activities relating to these three sectors: (1) the "primary sector" includes agriculture and mining industries; (2) the "secondary sector" covers manufacturing industry; and (3) the "tertiary sector" encompasses trade and service industries (Clark, 1940).

Nowadays, the tripartite division of economic activities is contested by the dissemination of a logic of service common to the three economic sectors (Almeida, 2005a; 2005b; 2008) and, in fact, the concerns of contemporary authors have been redirected towards an analysis of the "logics" of service, in particular in their symbolic and relational dimensions. Moreover, a similar change of paradigm is marked by reflection on the different tertiary "service products" in the aspects relating 
to their (im)materiality and to intellectual knowledge, which are now considered of central importance to human work.

A theoretical limitation has thus become evident in the tripartite classification of the sectors of productive activity - and, of course, productive work - especially in the face of the heterogeneous nature of each sector's functions and activities. For services, moreover, this issue is raised with greater acuity (Almeida, 2005a; 2005c; 2009a). For example, in one of the investigations that we had the chance to carry out in the course of our research history, the search for knowledge-work connected with the practice of an occupation in service companies represented, precisely, one of the interviewees' main concerns (table 5):

Table 5. Synopsis of the Conclusions of the Research Project on Information Technology (IT) Use in Financial, Telecommunications and Computer Enterprises (2003)

“(...) On the issue of the adjustment of the new recruits' education and training to corporate needs, the managers interviewed mainly mentioned a university education, considering that this produced a minimum capacity to systematise and an ability to analyse. However, they considered that university curricula should include two types of competence: a stronger relationship with companies and incentivation to develop a proactive and motivated attitude. In concrete terms, the managers repeated the need for a good knowledge of business environments (through regular and/or protocol-based training courses) and project management skills (on the assumption of the across-the-board reality of the logic of service).

In terms of the economic situation and the supply and demand of IT professionals on the labour market, supply is seen as exceeding the demand that exists, now that the bubble associated with three fundamental phenomena has passed: the millennium, the introduction of the euro and the internet boom. The managers interviewed also mentioned a relative levelling of salaries and an increase in quality in the supply of professionals; this situation (in 2003) contrasts with the earlier state of the labour market (in 2001) when the lack of IT professionals and the difficulty in recruiting them were a recognised fact."

It was at the end of the 1970s that Gershuny's theory of the "self-service economy" confuted Bell's theory of the post-industrial society. Gershuny's basic criticism of Bell's theses was that an analysis of consumer demand for goods and services should not be directly based on families of goods or services: they should take into account families of needs or functions satisfied or performed by those goods. A fortiori, consumers do not buy a good or service for itself, but according to their needs or the functions of that good or service (Gershuny, 1978; Gershuny, 1983). To a certain extent, Gershuny's observations opened the way - as far as we are concerned - to a 
new trend in analysing tertiarisation phenomena in advanced societies and terminated a cycle in the observation and interpretation of reality that was more economic than sociological.

In 1992, Baumol proposed that the economy could be divided into two sectors: a "progressive sector", in which the introduction of technology allows profit to be gained from work productivity, and a (stagnant) "non-progressive sector", in which the work performed is itself, in fact, a final output (considered to be the case for many services) and productivity is stationary. This supposed dualism of post-industrial economies leads to a transfer of labour to less dynamic sectors and a paradoxical and unbalanced sense of growth: (1) on the one hand, it is the less dynamic production that absorbs the essential part of the profits and workforce; but (2) on the other, it is this workforce that, predominantly, leads to an inevitable fall in productivity and slower growth (Baumol, 1992).

It was Gadrey who, later, sought to demonstrate the inappropriacy of industrial productivity measures to gauge the productivity of services (Gadrey, 1996; Gadrey, 2000). He proposed an analysis with multiple criteria, which fundamentally represented a theoretical recognition of the conceptual limitations of industry-based evaluations, which were still widespread at the time. The author thus opened the way to a correlative analysis of servicelisation in the three "sectors" of activity and human labour...

Within the context of the net economy, the dissemination of the "logic of access" (Rifkin, 2000) also implies the attachment of greater importance to service relationships: customers/users now tend to pay, above all, for "access" or "an experience" and not so much for "a good". The recent development of theories on the growth in services has thus been marked by two explanatory hypotheses: (1) at both the macro and micro economic level there is systematic growth in the added value of tertiary activities in terms of GDP (Gross Domestic Product); (2) this development in services also corresponds to a new phase in the development of societies: it is a question of another quantitatively dominant production model and not a new sector that is developing in parallel with the others ${ }^{5}$. 


\section{Conclusion: current issues in the servicelisation of modern work}

In our research work we have used the concept of "servicelisation": (1) in contrast to the concept of "industrialisation" and, alternatively, (2) as a means of describing the phenomenon of the transversality of the "logic of service" in the organisation of a considerable and growing number of contemporary modern work activities (Almeida, 2005a; 2005b; 2009a). We distinguish the concept of "service" from that of "services", not only associating "services" with the official classification of economic activities but also postulating that "service" cuts across, or is transversal to, most forms of contemporary work.

We can illustrate this effect of servicelisation practices on the organisation rationales of human labour with an experiment that we were able to follow very closely. More precisely, it relates to the introduction in Portugal of practices and policies for managing human resources in banking enterprises, with the aim of individualising contractual relationships and gradually retreating from negotiation mechanisms. The process was based on consultancy methodologies introduced from the United States, identifiably in the second half of the 1980s, although its effects on the sector extended throughout the 1990s.

It is worth mentioning that it was the importation of an integrated human resources management system that represented the principal difference in relation to earlier practices. The system used a points-based classification of functions (specifically, the Hay Group Method), evaluating performance in connection with the calculation mechanisms for the salaries to be paid. Moreover, among other considerations, it used a methodology that analysed professional training needs and delivered a forecast on employees and their future career potential. In our point of view, these characteristics will certainly justify a future exercise in the "archaeology" of work forms and their transformations, which are of fundamental importance to the recent history of service organisations in Portugal (Almeida, 2005a).

Furthermore, this aspect will be all the more significant if we consider, in particular, the importance that IT-use policies have been acquiring - as we were able to ascertain in a piece of research that we carried out in 2000 (table 6):

\footnotetext{
$5 \quad$ Analyses of post-industrialism reflect the following postulate (Almeida, 2005b; De Bandt and Gourdet, 2001): the agricultural phase corresponded to a "society of basic goods", the industrial phase to a "society of tangible goods" and the post-industrial or services
} 
Table 6. Synopsis of the Conclusions of the Research Project on Information Technology (IT) Use in Financial Intermediation Enterprises (2000)

“(...) The internal structure of organisations is adapted to this heavily IT-based business thinking. There are even cases in which external distribution channels (the internet, for example) are simultaneously the support for internal organisational systems (in terms of production flows). Moreover, all the banks and insurance companies analysed have departments dedicated to the management and implementation of IT-use policies, on account of the complexity, as well as the pioneering, of these organisations in these aspects. The quality of the supply, the quality of the products (variety, reliability, degree of sophistication etc.) and the extent of the commercial network (closeness of the branches, kind of service, image, specificity etc.) seem to guarantee a longer-lasting competitive edge. In other words, in the case of banking, the ability to compete is associated with the ability to respond holistically to its customers' financial concerns (a global range of products and advisory services, among other things). Most of all, the large and medium-sized banking organisations consider that this new technology field will be capable, in the future, of being entrusted with all new developments, e.g. advances in and options for new distribution channels.

In most large organisations, computer resources are assigned according to the type of user. Internet access is seen as a certain source of complications since the net itself is considered highly recreational: access is generally restricted to work positions that justify its use. There are cases in which the strategy adopted is based on the head of department's proposal that a certain work position should have access. This is accompanied by awareness-raising instruction for new recruits, to whom, in addition to the training received, the rules of IT access and use are explained. In these companies, the areas indicated as justifying internet use the most are the administrative and commercial sectors and the marketing areas."

A final note on the relationship between the "servicelisation" and "commodification" of human labour.

The act of analysing the processes in the servicelisation of contemporary work within the framework of advanced capitalist societies will imply - according to our thesis - considering the value of the tertiary product differently: a "use value", in addition to a "production value", in which the creative elements, of knowledge-work and emotional intelligence, are markedly present. For this reason, servicelisation as a concept possesses an explanatory potential for a critique of Braverman's theories of human capital and the degradation of work. Moreover, within the framework of the dynamics of servicelisation, the division between the concepts of "machine" and "work" becomes fuzzier: it is, therefore, within the framework of the distribution of skills and technical knowledge that the differentiation strategies of the actors are played out on the labour market.

phase to a "society of intangible goods". 
The "socialisation of management" takes place with the officialisation of collective work contracts, which are combined, in a complex way, with individual contracts. According to Rolle, for example, it is this array of contracts at different levels and with different regulatory agents that limits, organises and dissimulates subordination, a central aspect of labour market contracts (Rolle, 1997).

In our view, it is an important and evident fact that these ways of maintaining the employeeemployer relationship have also helped to increase the cases of a link between pay and performance. This phenomenon goes hand in hand with the increase in the number of enterprises using alternative criteria to assess and reward workers (Almeida, 2005a; 2005c; 2009c). This perspective of management is based on the hypothesis that an organisation can identify and measure individual behaviour in such a way as to lead a person to perform a given function effectively. In its turn - in this individualistic reasoning - such behaviour is assumed to constitute the basis of a "pay package" that stimulates the development and use of poorly developed qualification or skills.

\section{References}

ALMEIDA, Paulo Pereira de (2005), "The 'servicelization' of societies: towards new paradigms in work organization", Portuguese Journal of Social Science, Vol. 4, No. 2, pp. 63-79.

ALMEIDA, Paulo Pereira de (2008), "Technology and the 'servicelization' of labour: from immateriality to innovative uncertainty", Portuguese Journal of Social Science, Vol. 7, No. 2, pp. 103114.

ALMEIDA, Paulo Pereira de (2009a), The Service Enterprise: a key concept for the Sociology of Work, New York, VDM Verlag Publishing.

ALMEIDA, Paulo Pereira de (2009b), "Tertiary employment, servicelisation of work and technological systems" in António Firmino da Costa, Fernando Luís Machado and Patrícia Ávila (orgs.), Portugal in AUBRET Jacques et al. (2002), Management des Compétences: réalisations, concepts, analyses, Paris, Dunod.

AUSTER, Carol Jane (1996), The Sociology of Work: concepts and cases, California, Pine Forge Press. 
BAUMOL, William J et al. (1992), Productivity and American Leadership. The Long View, Massachusetts, MIT Press.

BECK, Ulrich (2000), The Brave New World of Work, London, Polity Press.

BILHIM, João (2001), Teoria Organizacional: estruturas e pessoas, Lisbon, Instituto Superior de Ciências Sociais e Políticas.

BILHIM, João (2002), Questões Actuais de Gestão de Recursos Humanos, Lisbon, Instituto Superior de Ciências Sociais e Políticas.

BILHIM, João (2009), Gestão Estratégica de Recursos Humanos, Lisbon, ISCSP.

BOREHAM, Paul et al. (2008), New Technology @ Work, New York, Routledge.

BRIDGES, William (1994), JobShift: how to prosper in a workplace without jobs, Massachusets, Addison-Wesley.

CABRAL, Manuel Villaverde et al. (orgs.) (2000), Trabalho e Cidadania, Lisbon, Instituto de Ciências Sociais.

CARON, Louise Jeanne (2002), La Métaphore au Service de la Clientèle: ou la construction de systèmes informatiques intégrés, Paris, L'Harmattan.

CLARK, Colin (1940), The Conditions of Economic Progress, London, Macmillan.

COUTROT, Thomas (1998), L'Entreprise Néo-libérale, Nouvelle Utopie Capitaliste? Enquête sur les Modes d"Organisation du Travail, Paris, Éditions de La Découverte.

DE BANDT, Jacques and GOURDET, Geneviève (dir.) (2001), Immatériel: nouveaux concepts Paris, Economica.

DE COSTER, Michel et al.(2004), Traité de Sociologie du Travail, Brussels, De Boeck-Wesmael.

DENT, Harry S. (1995), Job Shock: four new principles transforming our work and business, New York, St. Martins Press.

ERBÈS-SEGUIN, Sabine (1999), La Sociologie du Travail, Paris, Éditions de la Découverte.

FISHER, Allan (1935), The Clash of Progress and Security, London, Macmillan.

FISHER, Allan (1945), Economic Progress and Security, London, Macmillan.

FREIRE, João and ALMEIDA, Paulo Pereira de (2010) (orgs.), Trabalho, Moderno, Tecnologia e Organizações, Porto, Edições Afrontamento. 
GADREY, Jean (1996), Services: la productivité en question, Paris, Desclée de Brouwer.

GADREY, Jean (2000), Nouvelle Économie, Nouveau Mythe?, Paris, Flammarion.

GADREY, Jean and ZARIFIAN, Philippe (2002), L'Émergence d'un Modèle du Service: enjeux et réalités, Paris, Éditions Liaisons.

GERSHUNY, Jonathan (1978), After Industrial Society? The Emerging Self-service Economy, New Jersey, Humanities Press.

GERSHUNY, Jonathan (1983), The New Service Economy: the transformation of employment in industrial societies, New York, Praeger.

GRINT, Keith (2001), Work and Society: a reader, Cambridge, Polity Press.

HANDY, Charles B. (1995), The Age of Paradox, Massachusetts, Harvard University Press.

HEROD, Andrew (2009), Geographies of Globalization: a critical introduction, London, WileyBlackwell.

KOVÁCS, Ilona (2002), As Metamorfoses do Emprego: ilusões e problemas da sociedade de informação, Oeiras, Celta Editora.

KOVÁCS, Ilona and CASTILLO, Juan José (1998), Novos Modelos de Produção: trabalho e pessoas, Oeiras, Celta Editora.

REICH, Robert B. (2004), O Futuro do Sucesso: viver e trabalhar na nova economia, Lisbon, Terramar. RIFKIN, Jeremy (2000), The Age of Access: how the shift from ownership to access is transforming capitalism, New York, G.P. Putnams Sons.

ROLLE, Pierre (1997), Oú Va le Salariat?, Lausanne, Éditions Page Deux.

SCHNAPPER, Dominique (1998), Contra o Fim do Trabalho, Lisbon, Terramar.

STONE, Katherine (2009), Work after Globalization: building occupational citizenship, Los Angeles, University of California.

VELTZ, Pierre (2000), Le Nouveau Monde Industriel, Paris, Éditions Gallimard.

WILLIAMS, Steve and ADAM-SMITH, Derek (2006), Contemporary Employment Relations, Oxford, Oxford Press. 
ZARIFIAN, Philippe (2003), A Quoi Sert le Travail?, Paris, La Dispute.

ZARIFIAN, Philippe (2009), Le Travail et la Compétence : entre puissance et contrôle, Paris, Presses Universitaires de France. 